\title{
Development of a Preventive Maintenance Program for Tooling Used in Powder Slush Molding
}

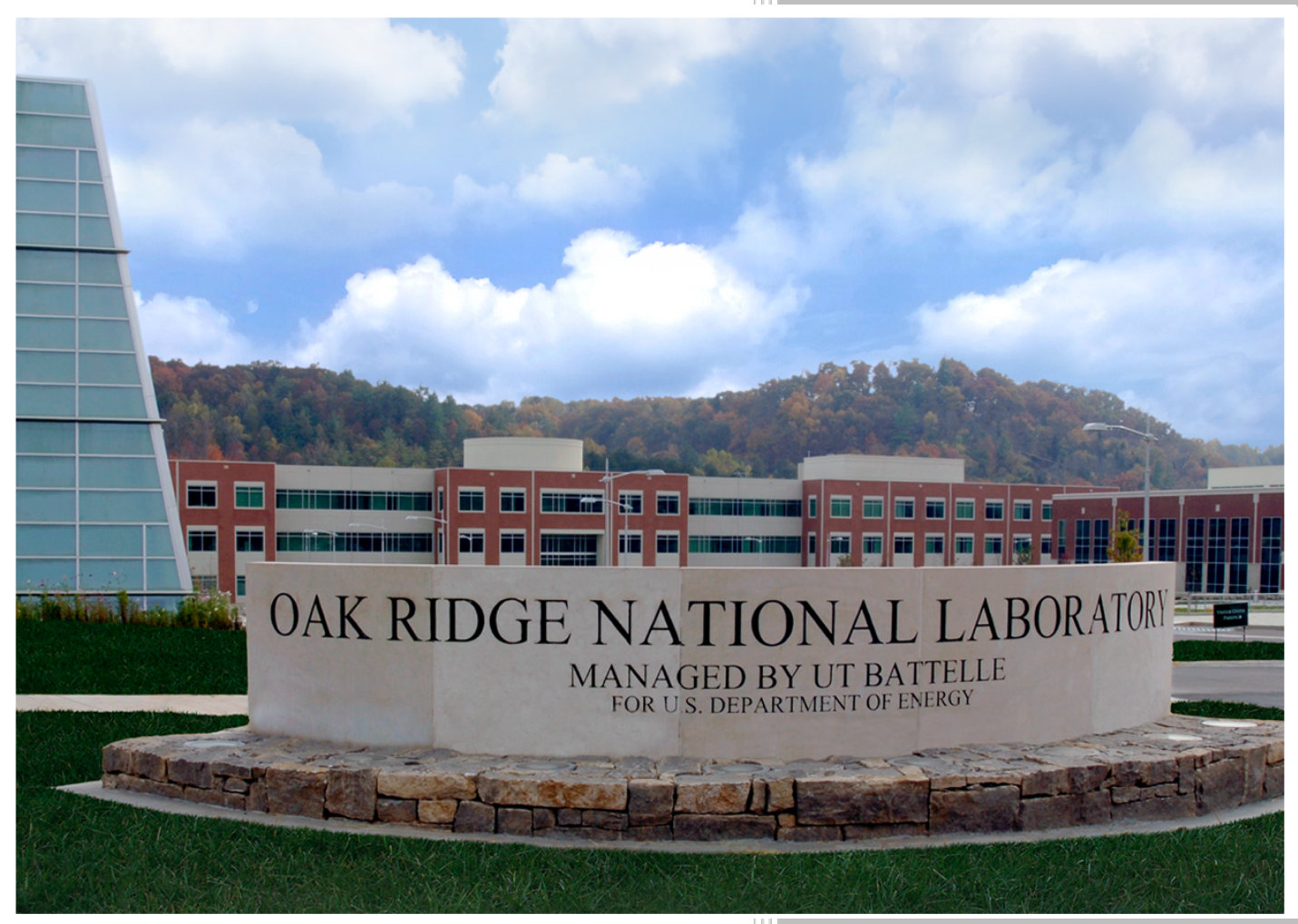

Edgar Lara-Curzio

July 19, 2016

CRADA FINAL REPORT
NFE-14-05312

Approved for Public Release. Distribution is Unlimited. 


\title{
DOCUMENT AVAILABILITY
}

Reports produced after January 1, 1996, are generally available free via US Department of Energy (DOE) SciTech Connect.

Website http://www.osti.gov/scitech/

Reports produced before January 1, 1996, may be purchased by members of the public from the following source:

\author{
National Technical Information Service \\ 5285 Port Royal Road \\ Springfield, VA 22161 \\ Telephone 703-605-6000 (1-800-553-6847) \\ TDD 703-487-4639 \\ Fax 703-605-6900 \\ E-mail info@ntis.gov \\ Website http://www.ntis.gov/help/ordermethods.aspx
}

Reports are available to DOE employees, DOE contractors, Energy Technology Data Exchange representatives, and International Nuclear Information System representatives from the following source:

Office of Scientific and Technical Information

PO Box 62

Oak Ridge, TN 37831

Telephone 865-576-8401

Fax 865-576-5728

E-mail reports@osti.gov

Website http://www.osti.gov/contact.html

This report was prepared as an account of work sponsored by an agency of the United States Government. Neither the United States Government nor any agency thereof, nor any of their employees, makes any warranty, express or implied, or assumes any legal liability or responsibility for the accuracy, completeness, or usefulness of any information, apparatus, product, or process disclosed, or represents that its use would not infringe privately owned rights. Reference herein to any specific commercial product, process, or service by trade name, trademark, manufacturer, or otherwise, does not necessarily constitute or imply its endorsement, recommendation, or favoring by the United States Government or any agency thereof. The views and opinions of authors expressed herein do not necessarily state or reflect those of the United States Government or any agency thereof. 
ORNL/TM-2016/223

CRADA/NFE-14-05312

Materials Science \& Technology Division

Advanced Manufacturing Office

\title{
Development of a Preventive Maintenance Program for Tooling Used in Powder Slush Molding
}

\author{
Authors \\ Edgar Lara-Curzio \\ Orlando Rios \\ Andres E. Marquez-Rossy
}

Date Published:

May 16, 2016

Prepared by

OAK RIDGE NATIONAL LABORATORY

Oak Ridge, Tennessee 37831-6283

managed by

UT-BATTELLE, LLC

for the

US DEPARTMENT OF ENERGY

under contract DE-AC05-00OR22725

Approved for Public Release 


\section{CONTENTS}

Page

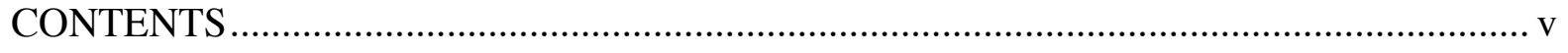

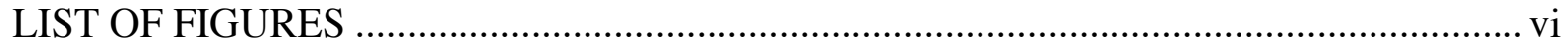

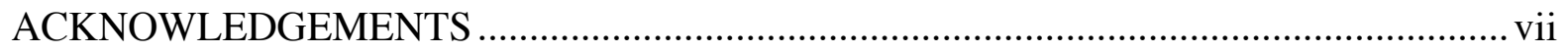

ABSTRACT ......................................................................................................... 1

1. Development of a Preventive Maintenance Program for Tooling Used in Powder Slush

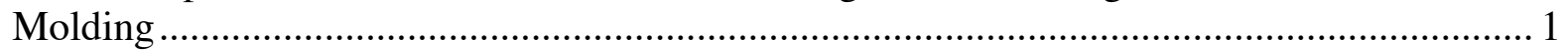

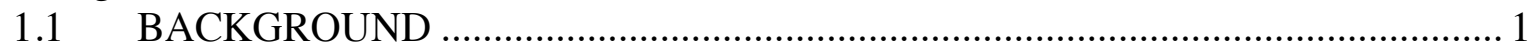

1.2 EXPERIMENTAL PROCEDURE ................................................................. 1

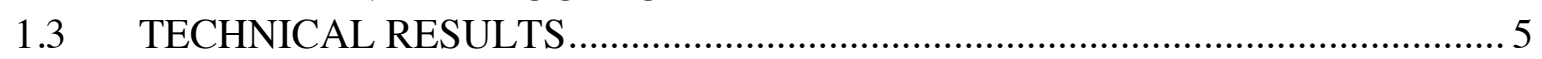

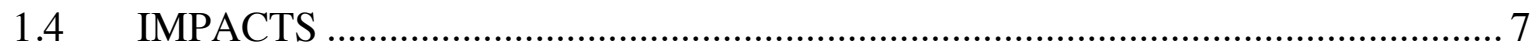

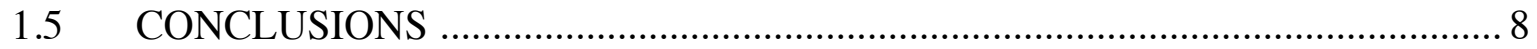

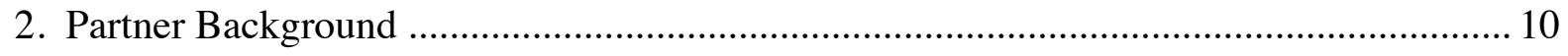




\section{LIST OF FIGURES}

Fig. 1. Picture of nickel tooling received from Faurecia for this investigation. ..................... 2

Fig. 2. Picture of nickel tooling with a segment removed............................................... 2

Fig. 3. Picture of plates manufactured by FET USA and by Weber................................... 3

Fig. 4. Electron backscatter diffraction image of nickel tooling on a plane parallel to the deposition surface. Grains were found to be equiaxed with $<001>$ texture. ......................... 4 Fig. 5. Electron backscatter diffraction image of nickel tooling on a plane perpendicular to the deposition surface. Grains were found to be columnar with random orientation............. 4 Fig. 6. Tensile stress-strain response for specimen N50 obtained from the mold in the as-

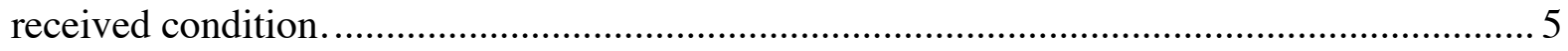
Fig. 7. Tensile stress-strain response for specimen N50 after an annealing treatment at $500^{\circ} \mathrm{C}$

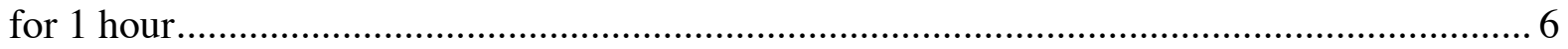

Fig. 8. Tensile stress-strain response for specimen N50 before and after an annealing

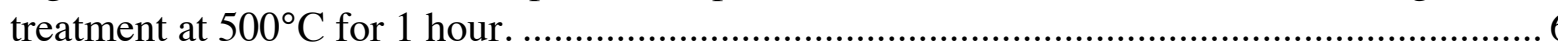

Fig. 9. Tensile stress-strain response for different specimens removed from the mold to illustrate the effect of both temperature and time of thermal annealing on the ability to remove strain hardening from the material.

Figure 10. Stress-strain curves obtained before and after annealing under a 1 Tesla magnetic

field at ambient temperature for different periods of time........................................... 8 


\section{ACKNOWLEDGEMENTS}

This CRADA NFE-14-05312 was conducted as a Technical Collaboration project within the Oak Ridge National Laboratory (ORNL) Manufacturing Demonstration Facility (MDF) sponsored by the US Department of Energy Advanced Manufacturing Office (CPS Agreement Number 24761).

Opportunities for MDF technical collaborations are listed in the announcement "Manufacturing Demonstration Facility Technology Collaborations for US Manufacturers in Advanced

Manufacturing and Materials Technologies" posted at

http://web.ornl.gov/sci/manufacturing/docs/FBO-ORNL-MDF-2013-2.pdf. The goal of technical collaborations is to engage industry partners to participate in short-term, collaborative projects within the Manufacturing Demonstration Facility (MDF) to assess applicability and of new energy efficient manufacturing technologies. Research sponsored by the U.S. Department of Energy, Office of Energy Efficiency and Renewable Energy, Advanced Manufacturing Office, under contract DE-AC0500OR22725 with UT-Battelle, LLC.

The contributions from Bart Murphy, Hsin Wang, William G. Carter and Christopher O. Stevens from ORNL's Materials Science \& Technology Division are greatly appreciated. The project also benefited from the participation of Jessica Faubel, Rebekah Kienenberger and Daniel Newmyer through the Siemens STARs program at ORNL. 


\begin{abstract}
ORNL collaborated with Faurecia Interior Systems to investigate the feasibility of developing a thermomagnetic preventive maintenance program for nickel tooling used in powder slush molding. It was found that thermal treatments at temperatures greater than $500^{\circ} \mathrm{C}$ can anneal strain hardening in nickel tooling and a range of temperatures and times for effective thermal annealing were identified. It was also observed that magnetic fields applied during thermal annealing do not alter the kinetics of strain hardening annealing. The results obtained in this investigation provide a foundation for establishing a preventive maintenance program for nickel tooling.
\end{abstract}

\title{
1. DEVELOPMENT OF A PREVENTIVE MAINTENANCE PROGRAM FOR TOOLING USED IN POWDER SLUSH MOLDING
}

This phase I technical collaboration project (MDF-TC-2014-51) began on January 31, 2015 and was completed on May 15, 2016. The collaboration partner Faurecia Interior Systems is a member of the Faurecia Group, which specializes in automotive seating, interior systems, automotive exteriors and emissions control technologies.

\subsection{BACKGROUND}

Nickel has been the standard tooling material for manufacturing slush molded instrument panel cover skins for automobiles and trucks for over 30 years. However, cracks that nucleate and grow in nickel tooling as a result of thermal fatigue, have a negative impact on product quality, productivity and costs. Cyclic thermal fatigue is a direct result of temperature gradients and thermal cycling, which are inherent to the slush molding process. In cyclic thermal fatigue, stresses arise from repeated thermally induced strains and the response of materials to these strains will depend on their yield strength and strain hardening characteristics. When sufficient strain hardening has occurred and dislocation motion has been hindered, dislocations tend to pile up at material discontinuities (edges, surfaces, grain boundaries), resulting in stress risers that lead to crack nucleation. Therefore, unpinning dislocations through annealing reestablishes the ability of these dislocations to move and therefore prevent stress concentrations.

The objective of this Cooperative Research and Development Agreement (CRADA) between UTBattelle, LLC and Faurecia Interior Systems was to determine the feasibility of using thermal and magnetic annealing treatments to remove strain hardening in nickel tooling used for manufacturing instrument panel cover skins for automobiles and trucks. The successful completion of this project could lead to the development of preventive maintenance methods to avoid the nucleation of cracks in nickel tooling for powder slush molding.

\subsection{EXPERIMENTAL PROCEDURE}

The test specimens used for this investigation were obtained from one decommissioned nickel powder slush mold that had been used to manufacture instrument panel cover skins for Ford's Focus C346 model. Figure 1 shows a picture of the mold shipped to ORNL from Faurecia's Louisville facility, while Figure 2 shows some of the segments removed from the mold from which test specimens were obtained. Additional test specimens were obtained from two plates procured by Faurecia from vendors Weber Manufacturing ${ }^{1}$ and FET USA ${ }^{2}$. Weber Manufacturing uses a nickel

1 www.webermfg.ca

2 www.fetusa.com/electroform-nickel-tooling.html 
vapor deposition process to manufacture nickel tooling while FET USA uses an electroplating process. Figure 3 shows a picture of the two plates. The surface texture to create leather-like features on the instrument panel cover skins is evident in the picture in Figure 3. Although electroplating is the most common method for fabricating powder slush molding tools, it yields molds with nonuniform thickness, particularly at corner regions or regions with sharp radii, where the mold is thicker than open areas of the mold. Molds with uniform thickness are preferred to minimize temperature gradients during the slush process, which tend to induce stresses.

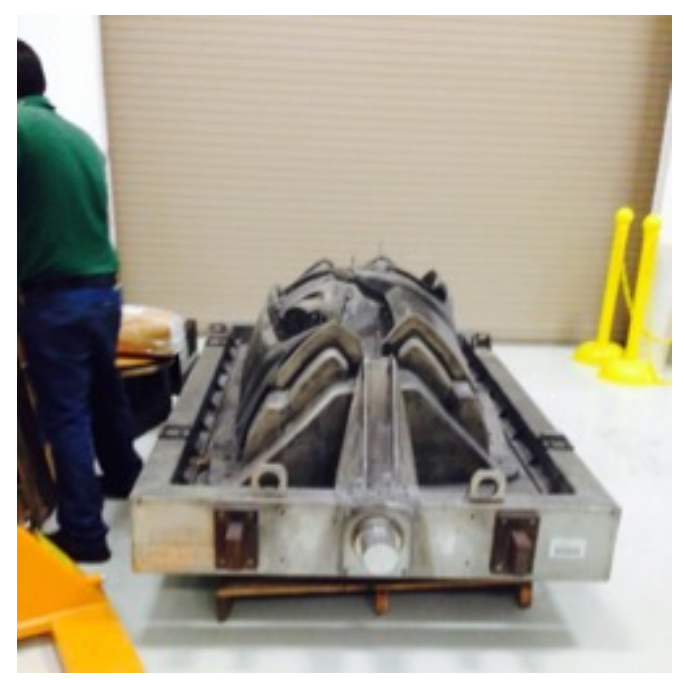

Fig. 1. Picture of nickel tooling received from Faurecia for this investigation. Note person on the left for scale.

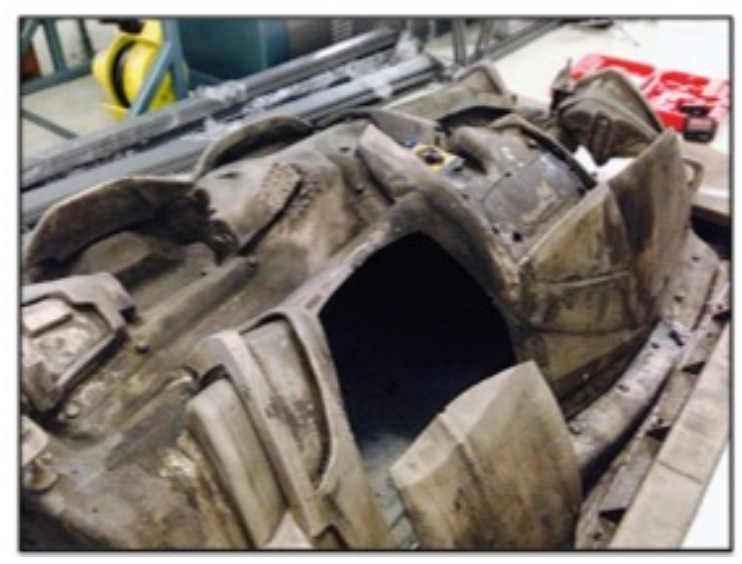

Fig. 2. Picture of nickel tooling with a segment removed. 


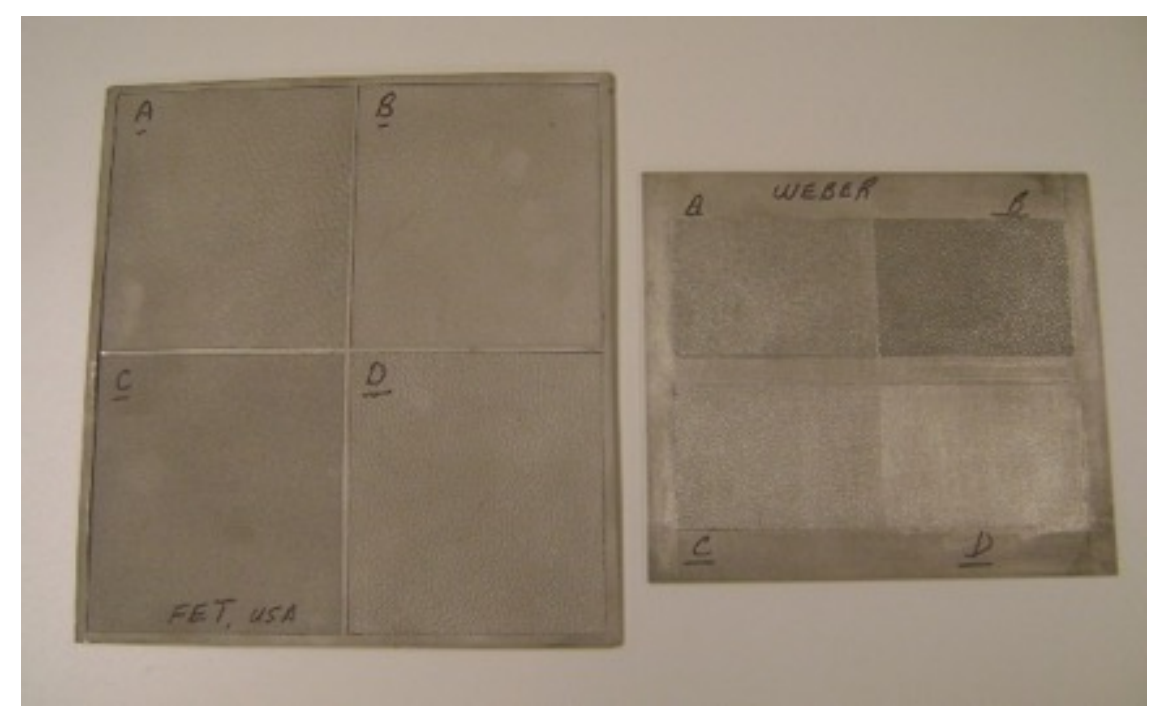

Fig. 3. Picture of plates manufactured by FET USA and by Weber.

Rectangular bars $12.5-\mathrm{mm}$ wide, $125-\mathrm{mm}$ long and with the nominal thickness of the mold were obtained using electric discharge machining (EDM) from segments removed from the mold using a reciprocating cutter with tungsten carbide blades. Rectangular bars of similar dimensions were obtained from the Weber and FET USA plates using water jet cutting.

Several thermophysical properties of the nickel tooling and the nickel plates were measured to characterize the material and to investigate the feasibility of using them to quantify its degree of strain hardening. These properties include: thermal expansion, heat capacity, electrical resistivity and Seebeck coefficient. The microstructure of the material, including grain morphology and grain crystallographic orientation, was characterized using electron microscopy and electron backscatter diffraction. For example, the micrographs in Figures 4 and 5 show electron backscatter diffraction images obtained on surfaces of the tooling that were parallel and perpendicular to the deposition direction. Planes parallel to the deposition plane consist of equiaxed grains with a strong $<100>$ texture, while grains on a plane perpendicular to the deposition plane are columnar. In addition to these measurements, the Vickers hardness and tensile stress-strain behavior of the nickel tooling and plates were determined.

Understanding the mechanical response of the material was essential to assess the effect of thermal annealing on the degree of strain hardening reduction within the material. The methodology consisted in subjecting test specimens to a tensile strain of $0.5 \%$ at a constant crosshead displacement rate. These tests were performed using a servohydraulic testing machine equipped with a load cell, a pair of hydraulically-actuated grips and an extensometer. All tensile tests were performed at ambient conditions. After the specimen reached $0.5 \%$ strain, it was unloaded, removed from the mechanical testing machine and subjected to thermal annealing with and without the application of an external magnetic field. Thermal annealing treatments were performed by embedding the test specimen in casting sand maintained under isothermal conditions inside a box furnace. Thermal annealing experiments were carried-out at different temperatures between $300^{\circ} \mathrm{C}$ and $700^{\circ} \mathrm{C}$ for different periods of time between 10 minutes and 10 hours. Thermal annealing experiments with superimposed magnetic fields were carried-out at ORNL's Magnetic Processing laboratory where temperatures were imposed by induction heating. Values of magnetic field varied between 0 Tesla and 9 Tesla.

After thermal annealing or thermal annealing with a magnetic field, test specimens were re-tested mechanically following the same protocol to a maximum tensile strain of $0.5 \%$. 


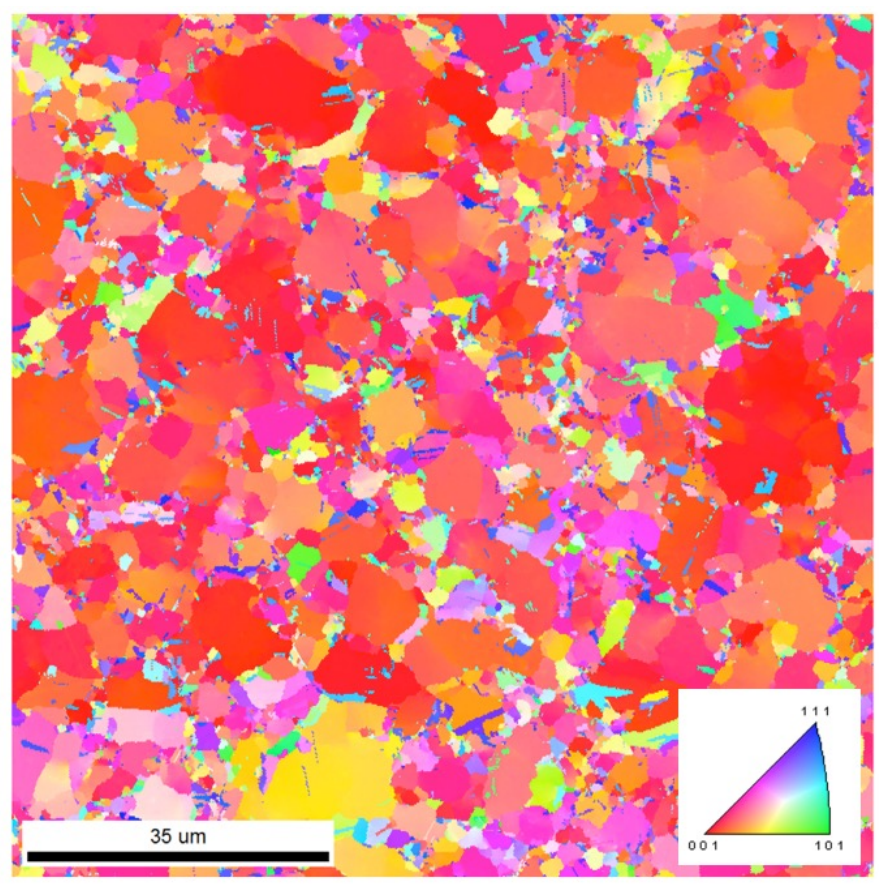

Fig. 4. Electron backscatter diffraction image of nickel tooling on a plane parallel to the deposition surface. Grains were found to be equiaxed with $<001>$ texture.

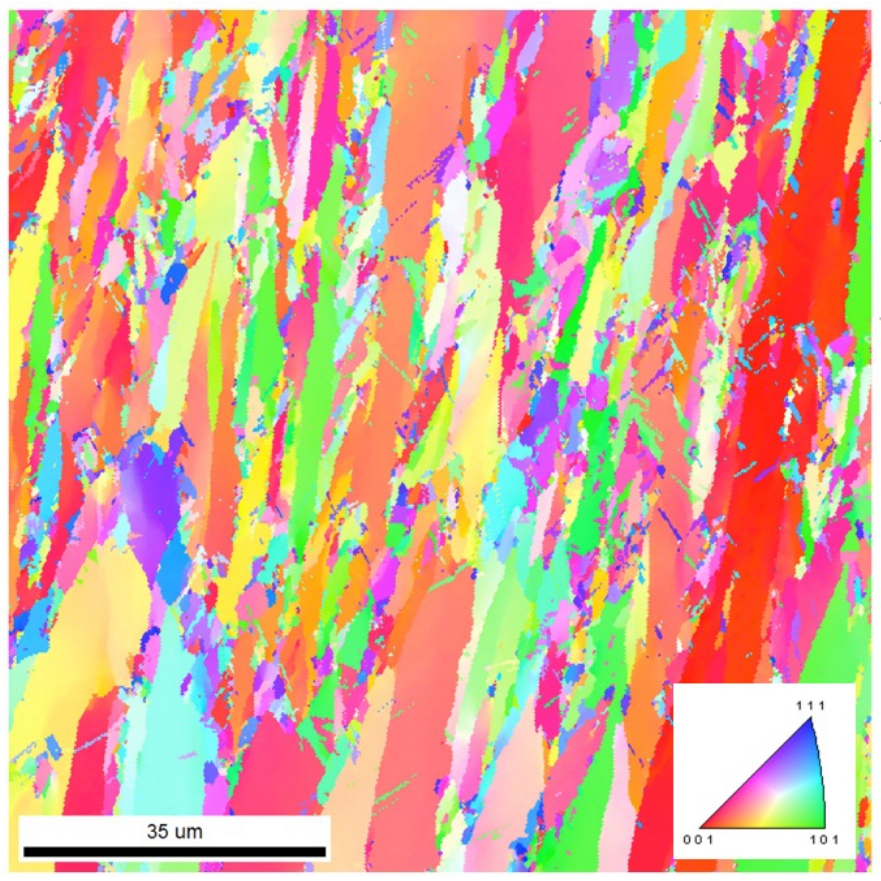

Fig. 5. Electron backscatter diffraction image of nickel tooling on a plane perpendicular to the deposition surface. Grains were found to be columnar with random crystallographic orientation. 


\subsection{TECHNICAL RESULTS}

Figure 6 shows the initial stress-strain response of a test specimen (specimen N50) obtained from the mold in the as-received condition. The curve shows features that are characteristic of the response of most metals: it has a linear region, an inflection point associated with yield and a positive slope at increasing strains, which is indicative of strain hardening. The yield strength was determined using the $0.05 \%$ offset method and a value of $192 \mathrm{MPa}$ was obtained. Figure 7 shows the response of the same test specimen after an annealing treatment at $500^{\circ} \mathrm{C}$ for 60 minutes without the application of a magnetic field. The shape of the curve is similar to that shown in Figure 6 for the as-received condition, except that the yield strength is lower (183 MPa vs. $192 \mathrm{MPa}$ ) and the rate of strain hardening is also lower after the annealing treatment. To highlight the differences in behavior both curves are plotted together in Figure 8. These results demonstrate the feasibility of thermal annealing treatments to remove strain hardening in nickel tooling that has accumulated during fabrication and subsequently service.

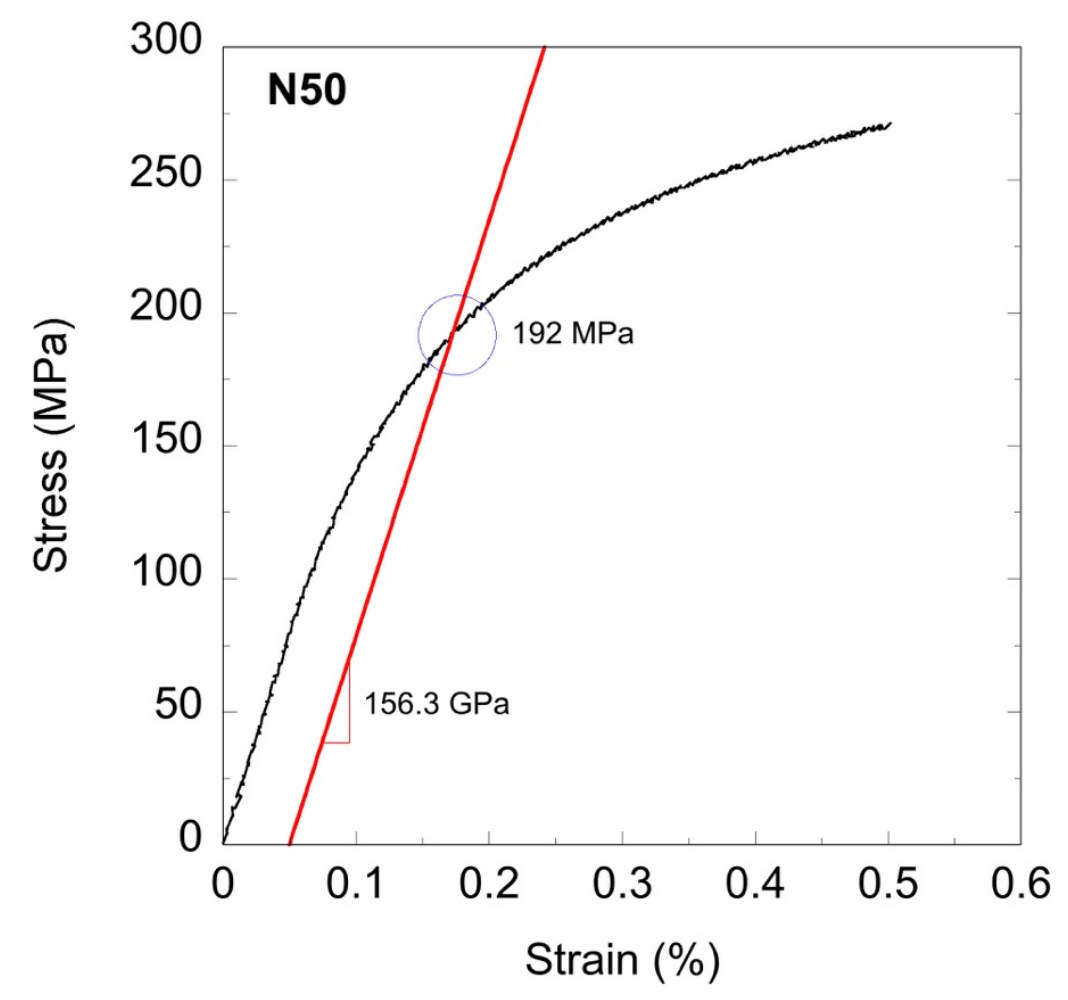

Fig. 6. Tensile stress-strain response for specimen N50 obtained from the mold in the as-received condition. The Young's modulus was found to be $156.3 \mathrm{GPa}$. 


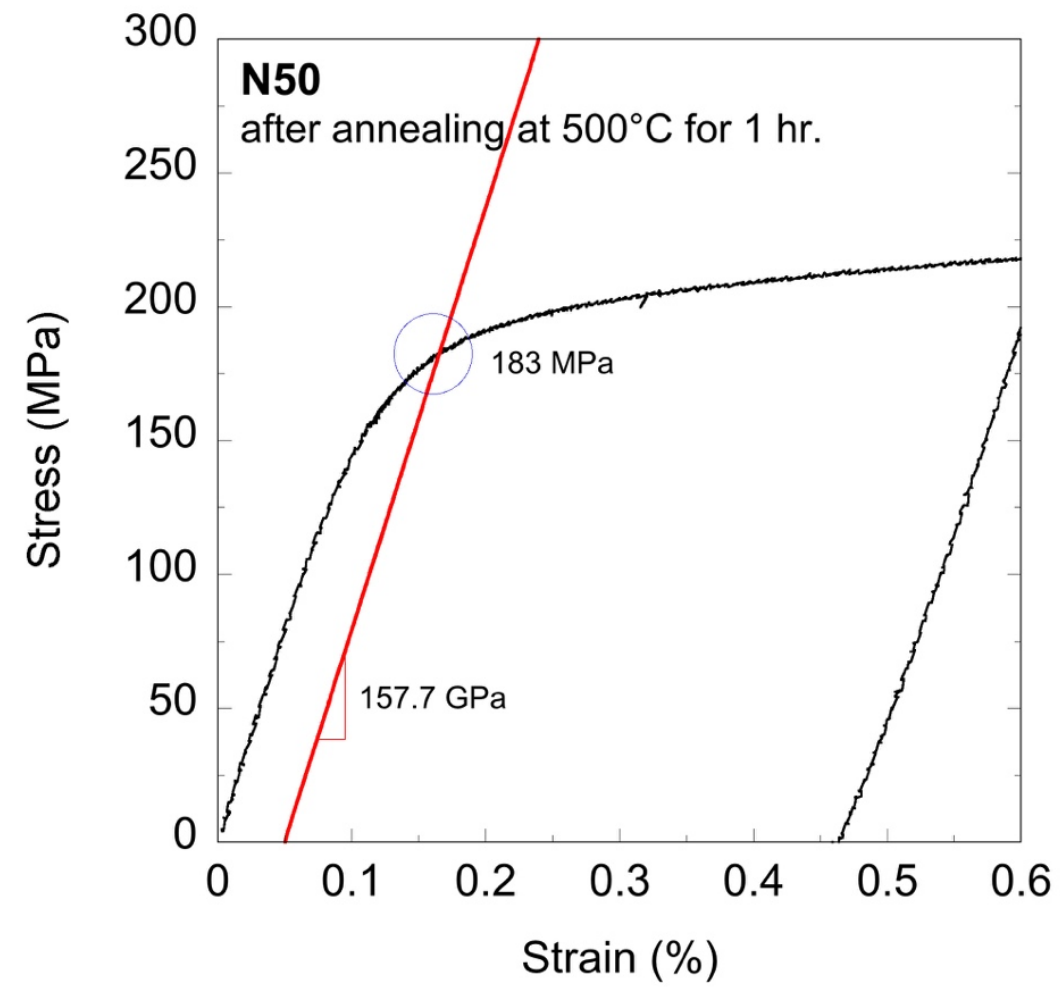

Fig. 7. Tensile stress-strain response for specimen $\mathrm{N50}$ after an annealing treatment at $500^{\circ} \mathrm{C}$ for 1 hour. The Young's modulus was found to be $157.7 \mathrm{GPa}$.

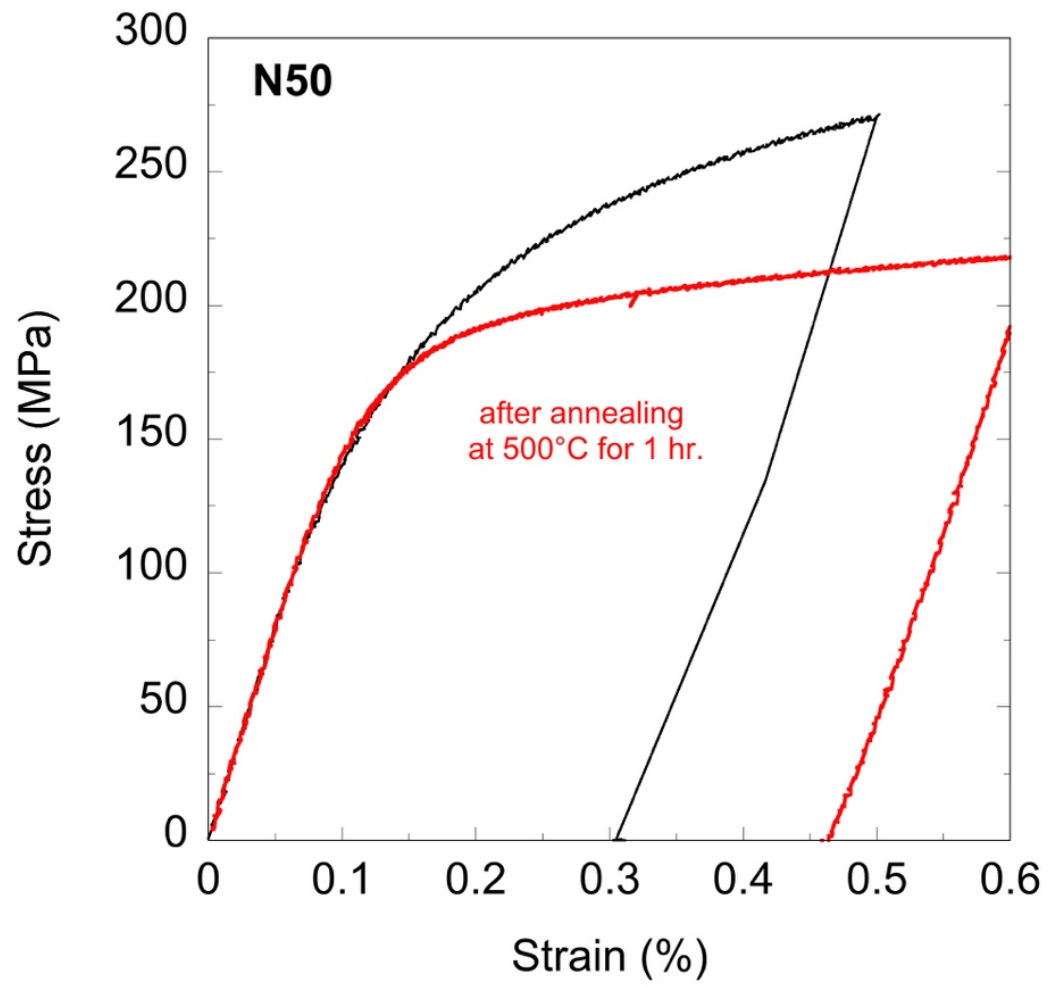

Fig. 8. Tensile stress-strain response for specimen $\mathrm{N} 50$ before and after an annealing treatment at $500^{\circ} \mathrm{C}$ for 1 hour. 
Figure 9 shows a collection of tensile stress-strain curves to illustrate the effect of both temperature and time of thermal annealing on the stress-strain behavior of the nickel tooling. These results show that no significant annealing occurs at $300^{\circ} \mathrm{C}$ even after 10 hours. However, the amount of annealing, as indicated by reductions in yield strength, increases with both temperature and time at temperatures between $500^{\circ} \mathrm{C}$ and $700^{\circ} \mathrm{C}$. The kinetics of thermal annealing are best illustrated by analyzing the stress-strain curves obtained after annealing at $700^{\circ} \mathrm{C}$. The results presented in Figure 9 provide a comprehensive set of data to determine the optimum combination of temperature and time for thermal annealing treatments of nickel tooling.

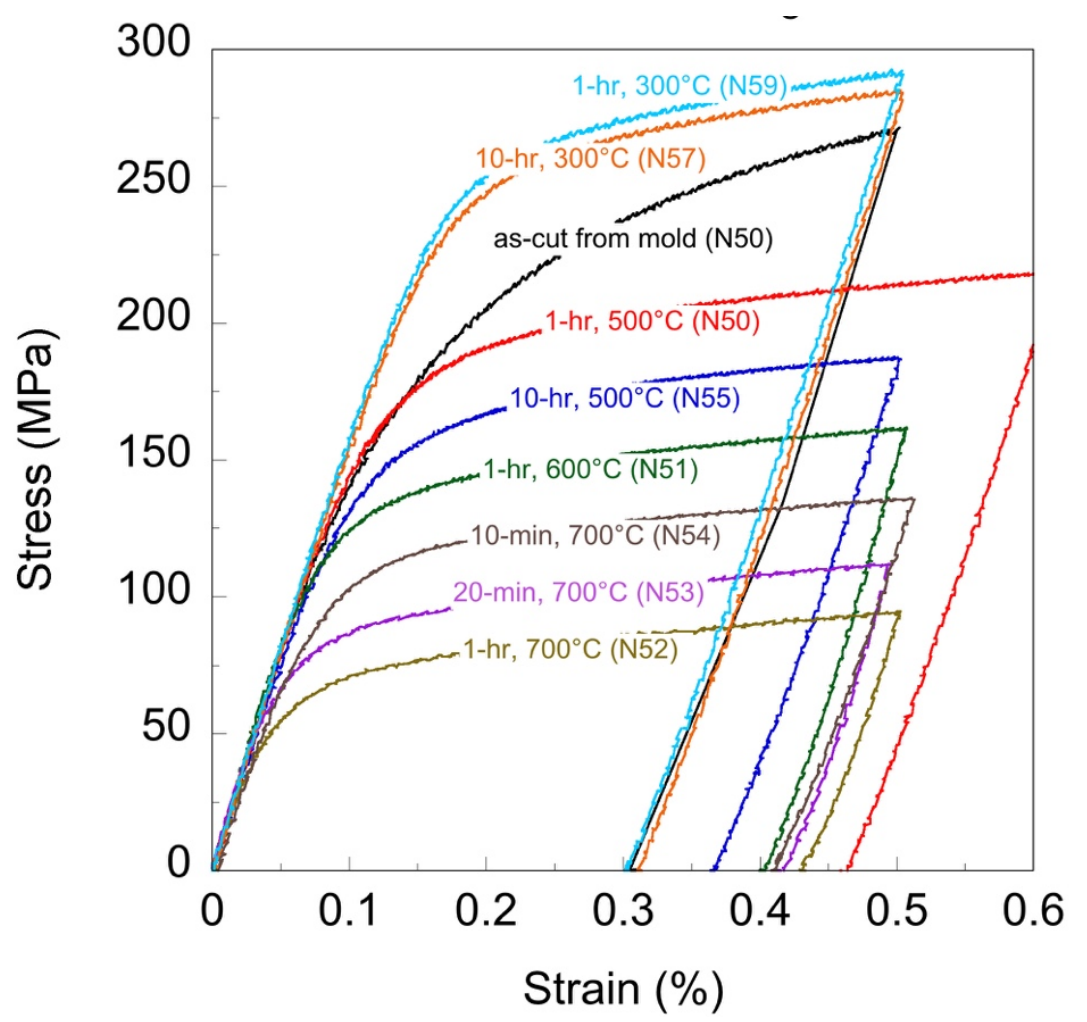

Fig. 9. Tensile stress-strain response for different specimens removed from the mold to illustrate the effect of both temperature and time of thermal annealing to remove strain hardening from the nickel tooling.

It was also found that, under the conditions considered in this investigation, the application of magnetic fields up to 9T and annealing times of 1,000 seconds do not have any effect on the kinetics of strain hardening annealing of nickel tooling for temperatures up to $700^{\circ} \mathrm{C}$. Figure 10 shows a series of stress-strain curves obtained before and after annealing under a 1 Tesla magnetic field at ambient conditions for different periods of time.

\subsection{IMPACTS}

Every major industrial manufacturing sector depends on tooling, and the ability to extend the service life of manufacturing tooling has a direct impact on both cost and energy savings. Specifically, the costs to repair or replace tooling, shipping costs, and costs associated with down time are critical. Furthermore, extending the service life of manufacturing tools has a direct impact on energy utilization by reducing the need for mining, manufacturing and transporting new manufacturing tools. 

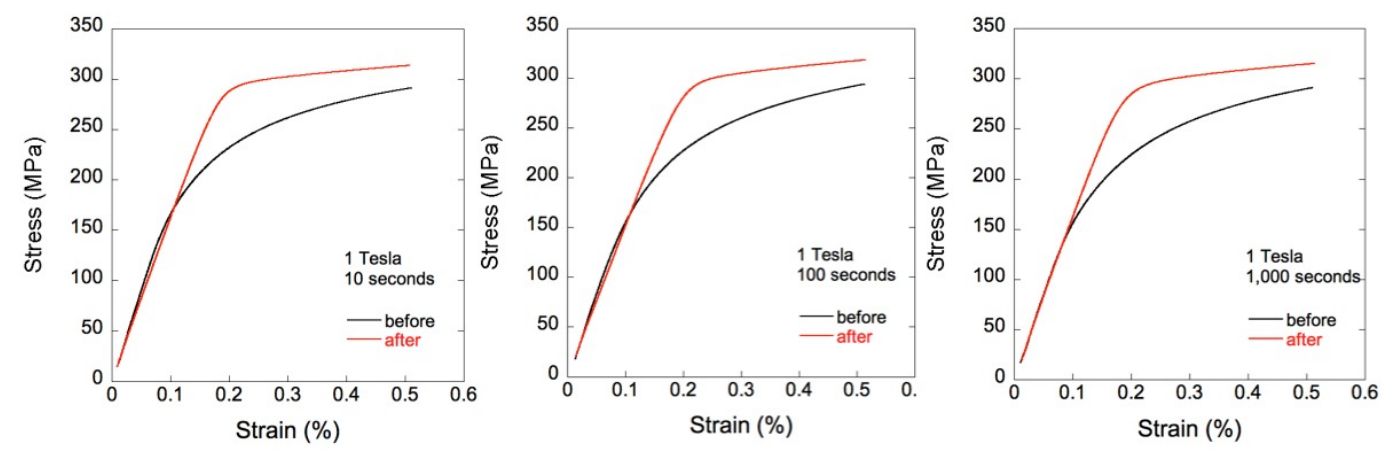

Figure 10. Stress-strain curves obtained before and after annealing under a 1 Tesla magnetic field at ambient temperature for different periods of time.

\subsection{CONCLUSIONS}

The effect of temperature, time and magnitude of magnetic field on the annealing behavior of nickel tooling was investigated. It was found that strain hardening in nickel tooling can be annealed through thermal annealing treatments at temperatures greater than $300^{\circ} \mathrm{C}$. Furthermore, the degree of annealing was found to increase with the duration of the annealing treatment.

For the annealing treatments temperatures and duration investigated, it was found that magnetic fields up to 9T, applied by themselves or superimposed to temperature, do not have an effect on the kinetics of annealing. The results from this investigation provide the foundation for designing preventive maintenance strategies for nickel tooling to remove strain hardening and prevent the nucleation of cracks that might result from thermal fatigue. 


\section{PARTNER BACKGROUND}

The Faurecia Group is a pioneer in technological innovations able to reduce the weight of vehicles, offer customized comfort and style solutions, and mitigate any impact on the environment. Faurecia is developing new manufacturing processes that are set to revolutionize its production methods. With 320 sites including 30 R\&D centers in 34 countries, Faurecia is a global leader in its four areas of business: automotive seating, interior systems, automotive exteriors and emissions control technologies. As the world's top supplier of vehicle interiors, Faurecia Interior Systems develops and produces:

- instrument panels and center consoles

- cockpits

- door panels and modules,

- $\quad$ acoustic products and modules

- decorative components (paint, film, wood, aluminum, etc.)

The Group draws on its specialized know-how in cut-and-sew techniques, applied to genuine leather as well as polyurethane- or PVC-based thermoplastics. Faurecia is also developing and integrating renewable, bio-based materials as part of a long-term campaign to produce lighter components. For example, one of its technologies combines natural hemp fibers with a polypropylene resin to yield a $25 \%$ weight reduction over glass-reinforced polypropylene. 